\title{
"Umělec nesmí nikdy ztratit odvahu, at' se děje, co se děje." Jan Novák a Bohuslav Martinů ve světle vzájemné korespondence (1947-1959)
}

\section{"The artist must never lose courage, whatever is happening." Jan Novák and Bohuslav Martinů in the Light of Mutual Correspondence (1947-1959)}

Martin Flašar / flasar@phil.muni.cz

Department of Musicology, Faculty of Arts, Masaryk University, Brno, CZ

Pavel Žůrek / pavel@martinu.cz

Bohuslav Martinů Institute, Prague, CZ

\begin{abstract}
The aim of the paper is to inform the professional public about the project of processing mutual correspondence of Jan Novák and his teacher Bohuslav Martinů in the years 1947-1959. Sources for this work are part of the unprocessed estate of Jan Novák relatively recently deposited in the Czech Museum of Music in Prague. The primary research on the subject of the project will be realized by the joint musicological team for the first time. The key motivating factor of this project is the centenary of the birth of composer Jan Novák in 2021, to which the joint research team of the Institute of Musicology of the Faculty of Arts of Masaryk University and the Bohuslav Martinů Department will direct the publication of a book publication. Since the personality of Jan Novák has so far lacked his own book monograph on life and work, as well as a catalogue of works, this publication should serve as the first representative professional entry into the issues of his musical thinking and complicated life path. At the same time, it should become a starting point for further biographical research, as Jan Novák's relationship with Bohuslav Martinů was crucial for his lifelong artistic orientation.
\end{abstract}

\section{Keywords}

Jan Novák, Bohuslav Martinů, correspondence, music, biography 


\section{Informace o projektu}

Za dva roky si budeme připomínat výročí 100 let od narození skladatele Jana Nováka (1921-1984). Vzhledem k tomu, že jeho dílo stále postrádá adekvátní zpracování v souhrnné monografii, rozhodli se autoři této studie připravit k tomuto výročí kompletní kritickou edici korespondence skladatele s jeho učitelem, mentorem a přítelem Bohuslavem Martinů. Tato korespondence byla teprve nedávno zpř́istupněna v pozůstalosti Jana Nováka uložené před několika lety rodinou skladatele v Národním muzeu - Českém muzeu hudby (NM ČMH). ${ }^{1}$

Cílem společného projektu je vydání knižní monografie zaměřené na vztah hudebního skladatele Jana Nováka (1921-1984) k jeho učiteli Bohuslavu Martinů, který byl rozhodující pro Novákovou tvůrčí estetiku. Výzkumný projekt bude založen na heuristické práci s nově získanou pozůstalostí Jana Nováka uloženou v NM ČMH. Kromě korespondence s Bohuslavem Martinů v letech 1947-1959, jejíž kritická edice bude tvořit základ tištěné monografie, pozůstalost zahrnuje další nezpracované materiály, které budou postupně zpracovány a analyzovány s ohledem na zaměření projektu.

Klíčovým motivačním faktorem projektu je 100. výročí narození skladatele Jana Nováka v roce 2021, ke kterému by připravovaná monografie měla být publikována MUNI Press v Brně (v roce 2020 si též připomeneme 130 let od narození Bohuslava Martinů). Vzhledem k tomu, že Jan Novák stále nemá vlastní monografii ani katalog díla (nepočítáme-li soupisy Wilfrieda Stroha a Jana Čižmáře), měla by tato publikace sloužit jako první reprezentativní vědecký vstup do jeho života a práce.

\section{„Správní hoši". Od newyorské epizody k celoživotní inspiraci}

S Bohuslavem Martinů se Novák setkal v srpnu 1947, kdy přicestoval do New Yorku. ${ }^{2}$ Vzhledem k tomu, že neznal místo jeho bydliště, vydal se adresu zjistit do redakce nejmenovaných českých novin v New Yorku (pravděpodobně to byly Newyorské listy). ${ }^{3}$ Bohuslav Martinů přebýval v 58. ulici poblíž Páté avenue na Manhattanu, kde byl jeho sousedem Rudolf Firkušný.

Martinů se k Novákově tvorbě zprvu stavěl kriticky, což mladého skladatele s vysokým sebevědomím zaskočilo. Koncert pro klavír a smyčcový orchestr, jehož instrumentaci dokončil v rámci Letních kurzů Boston Symphony Orchestra v Lenoxu (Berkshire) u Aarona Coplanda, Martinů označil za „křečovitou a školáckou záležitost“ a klavírní part za málo brilantní. ${ }^{4}$

1 Děkujeme za upozornění na tuto skutečnost paní Marii Štastné z NM ČMH.

2 Podrobněji ke studiu J. Nováka u B. Martinů viz FLAŠAR, Martin. Jan Novák, žák Bohuslava Martinů. Hudebni věda, 2006, roč. 43, č. 1, s. 59-74.

3 Osobní deníkový zápis Evžena Zámečníka ze setkání s Janem Novákem, Singen, 1982, s. 11. Soukromý archiv E. Zámečníka.

4 ZOUHAR, Zdeněk (ed.). Bohuslav Martinu: Sbornik vzpominek a studii. Krajské nakladatelství v Brně, 1957. 
Novák své přítelkyni a pozdější manželce, klavíristce Elišce Hanouskové v dopise napsal: „Budu si Martinů vždy cenit jako geniálniho skladatele, i když se s ním možná brzo rozejdu. “5

Jak Novák uvádí, Martinů otřásl jeho skladatelskou sebedůvěrou, a proto zpočátku př́iliš nekomponoval. Brzy ovšem pochopil konstruktivní význam jeho kritiky a úvodní krizi překonal. O průběhu studia, které netrvalo ani půl roku (září 1947 - únor 1948) mnoho informací dosud nemáme. Podle dostupných informací se jednalo o nepravidelné konzultace, které s prohlubující se důvěrou získávaly osobnější charakter.

Od prvotního zhrzení získával Martinů v Novákových očích postupně status výjimečného skladatele. Martinů Nováka seznamoval s vlastní kompoziční metodou a zároveň odhaloval slabá místa Novákovy kompoziční práce. Tuto rovinu vztahu si oba skladatelé udrželi i v následujících dvanácti letech, jen v korespondenční formě.

Martinů Novákovi ze své bohaté knihovny půjčoval díla svých oblíbených skladatelů Arcangela Corelliho a Thomase Morleyho, ale i svoje vlastní partitury. Víme například, že si Jan do Čech přivezl partituru jeho 4. symfonie. ${ }^{6}$ Jak známo, Martinů se po skončení druhé světové války - nyní již jako světově hraný a uznávaný autor - chystal na návrat do Československa. Již v ř́ínu 1946 obdržel z Prahy zprávu o svém jmenování profesorem skladby na pražské Konzervatoři a ihned poté byl také „prozatímně pověřen“ výukou skladby na nově založené Akademii múzických umění v Praze. Na toto místo však nikdy nenastoupil. Kromě toho se také chystal na druhý ročník festivalu Pražské jaro, na kterém měl zaznít jeho 3. klavírní koncert, který psal pro Firkušného. Novák odplul z New Yorku začátkem února a do Československa se vrátil 25. února 1948, v den komunistického puče. Bezprostředně po Novákově odjezdu z USA 14. února 1948 Martinů napsal svému dlouholetému příteli z České filharmonie Karlu Novákovi:

„Měl jsem zde jednoho žáka, velmi slibný talent a moc hodný hoch, doporučuji ti jej vřele, ujmi se ho, až se vrátím, vezmu si ho do classy; je to tvioj jmenovec, myslím, že jste už od něho v Praze něco hráli. Jmenuje se Jan Novák, já si od něho hodně slibuji, protože je nejen nadaný, ale i velmi citově založený a vážný hoch. "

Nadšení bylo oboustranné. Ještě dva roky před svou smrtí (tedy v r. 1982) napsal Jan Novák Evženu Zámečníkovi:

„Nedávno jsme slyšeli v rádiu Inkantace s Firkušným. To už jeden ani nebledne závistí, protože je to božská muzika - tedy ta kategorie, kam řadím nĕjaké Mozarty a snad jiných pár znamenitců. [...] Jak se do této kategorie dostat nevi ani ti, co tam jsou, ale řekl bych, že to neni jenom hudebni zdatnost, ale hraji v tom úlohu i jiné hodnoty, stač si vzpomenout na Haydna nebo Dvořáka či Martinů, byli to celkem prostí lidé, ale jaksi správni hoši. No jo, ty meditace ponechme hudebním vědcuim. My dèláme, co můžeme, a ostatni neni naše starost."8

5 NOVÁK, Jan. Deníkové zápisky. Pozůstalost Jana Nováka. NM ČMH, Praha.

6 BLATNÝ, Pavel. Tři zastavení s Janem Novákem. Hudebni rozhledy, 1990, roč. 18, s. 277. Zřejmě se jednalo o dobovou reprodukci, tzv. blueprint, protože tiskem partitura vyšla poprvé až v roce 1950 v Boosey and Hawkes.

7 Mihule, Jaroslav, op. cit., 2002, s. 414.

8 NOVÁK, Jan. Dopis Evženu Zámečníkovi, 17. 11. 1982. Tiskem in HRABAL, František. V kontextu tvorby. Praha: Arbor Vitae, 2006, s. 294. 


\section{„Krátce řečeno jsi lajdák". Aktuální stav bádání}

Korespondence Nováka s Martinů a o Martinů z let 1947-1959 byla až do nedávné doby považována za ztracenou a o její existenci jsme věděli jen na základě nepřímých odkazů a sdělení, jako je například toto, uvedené v nekrologu B. Martinů:

„Mám těch Vašich dopisů přehršli pečlivě svázaných stužkou a pomalu abych se smiřoval se skutečností, že už k nim nic nepríibude. "“

Doposud bylo publikováno jen několik dopisů. Např́íklad dopis, který poslal Martinů Novákovi v březnu 1948 z USA do Československa, ve kterém Martinů zaznamenává svůj špatný zdravotní stav a komentuje úmrtí Jana Masaryka:

„Milý Jene, mnoho události se odehrálo od okamžiku, kdy jste vstoupil na lod', jež Vás dovezla do nové Europy. Dnes jsme zde všichni, i ti přespolni, hluboce vzrušeni nad tragickou smrtí Jana Masaryka.

Děkuji Vám za rychlé zprávy $i$ za Vaši starost o můj př́jezd na Festival. Mưj zdravotni stav neni zcela dobrý a tak můj návrat je zase oddálen. Na kdy? Nevím. Je mi toho velmi líto, že nebudu pokračovat s Vámi v začaté práci, ale jsem si jist, že si už dovedete poradit sám. Já ve Vás věrím a nezapomeňte na to, o čem jsme jedno odpoledne mluvili, že umělec nesmi nikdy ztratit odvahu, at’ se děje, co se děje, a že celý boj neni vyhrán v jedné kompozici ani v jednom roce. Já vím, že na to nezapomenete. "10

Nebo Martinů dopis zaslaný Novákovi v únoru 1959, ve kterém Martinů hodnotí Novákův nonet Balletti a 9:

„Milý Jeniku, odpověděl jsem ničemně na Tué dopisy a tak to ted poněkud napravuji. Doufám, že se máte dobře na těch Kniničkách a že máte hodně starosti s umistěním nábytku, piana a tak dále a s rukopisy i prázdným papirem, který čeká, aby byl pokryt hudebnimi myšlenkami. A když už jsem u nich, tedy jsem prohlédl Tvoje Baletti, je v nich jiskra, ale znovu Ti musím potvrdit, že si to dèláš moc lehké, zastavís se u prvního nápadu, vyždímáš jej, až z něho nic nezbude, a teprve pak se koukáš po nápadu novém, zkrátka že si s tím nehrajě̌, ačkoliv je v tom materiálu dost, který leži nevyužitý; krátce řečeno jsi lajdák."11

Při předběžném konstatování stavu bádání o skladateli Janu Novákovi nalezneme téměř stovku specializovaných studií, článků, diplomových prací, kapitol knih, slovníkových hesel a vzpomínek.

V posledních letech jsme se Janu Novákovi věnovali v separátních sondách, které zkoumaly např. jeho vztah k Bohuslavu Martinů a dalším českým skladatelům (napřr. Leoši Janáčkovi), používání latinského jazyka a latinské poezie, práci s folklorem, filmo-

9 NOVÁK, Jan. Poslední dopis Bohuslavu Martinů. Host do domu, VI, 1959, s. 462.

10 MARTINŮ, Charlotta. Můj život s Bohuslavem Martinů. Supraphon: Praha, 1971, s. 76-77.

11 MARTINŮ, Charlotta, op. cit., s. 118. 
vou hudbu, kulturní a politický kontext jeho života, metodologické možnosti konstrukce jeho biografie apod. Nejaktuálnějším př́íspěvkem je heslo v Českém hudebním slovníku:

- FLAŠAR, Martin. Novák, Jan 2) [heslo]. Český hudebni slovnik [online]. Rev. 19. 7. 2016. URL: 〈http://www.ceskyhudebnislovnik.cz/slovnik/index.php?option=com_ mdictionary\&task $=$ record.record_detail\&id $=6475>$.

- FLAŠAR, Martin. The twilight of novelists. The search for a multidimensional model of contemporary musical biography. In Music Biography Conference, Institute of Musical Research, University of London. 2015.

- FLAŠAR, Martin. Jan Novák - cizinec ve vlastní zemi. In Harmonie. Praha: Muzikus, 2014, s. 10-12, ISSN 1210-8081.

- FLAŠAR, Martin. Elements of Czech and Moravian folklore in the production of Bohuslav Martinů and his pupil Jan Novák. In Semiotics of Cultural Heritages - Remembering, Restoring, Renewing, ISI, Imatra, Finland, 8 - 11 June 2013.

- FLAS̆AR, Martin. Jednota v rozmanitosti, nebo Tisíc plošin? Ke konstrukci modelu monografie o Janu Novákovi. In Bajgarová, Jitka. K otázkám monografického pojeti skladatelské osobnosti a výkladu jejiho díla: $k$ 90. narozeninám skladatele a dirigenta Karla Husy. Vyd. 1. Praha: Etnologický ústav Akademie věd České republiky, 2013, s. 155-160. ISBN 978-80-87112-73-1.

- FLAŠAR, Martin. Jan Novák a Jiří Trnka: příspěvek k 50. narozeninám Kybernetické babičky. In 47. mezinárodni hudebněvědné kolokvium Brno: Genius loci, 2012.

- FLAŠAR, Martin. Smyčcové kvartety Jana Nováka. Musicologica Brunensia, 2012, 47, 2, s. 17-22. ISSN 1212-0391.

- FLAŠAR, Martin. Jana Nováka hra se skleněnými perlami: skladatel a řadové techniky. Musicologica Brunensia, 2011, 46, 1-2, s. 81-87. ISSN 1212-0391.

- FLAŠAR, Martin. Jan Novák: Musica Poetica Latina. Od nesmrtelnosti jazyka k nesmrtelnosti hudby? Musicologica Brunensia, 2010, 45, 1-2, s. 95-102. ISSN 1212-0391.

- FLAŠAR, Martin. Martinů nebo Janáček? Janáčkovské aluze v tvorbě Jana Nováka. In 30. ročnik muzikologické konference Janáckiana 2010 „Moravsko-slovenské folklorni inspirace v čské a slovenské hudbě (Janáček, Novák, Martinů a jejich následovníci)“. Ostrava: Ostravská univerzita - Pedagogická fakulta, 2010. 8 s. ISBN 978-80-7368-576-8.

- FLAŠAR, Martin. Aus dem Schatten hervortreten - Bohuslav Martinu und Jan Novak. Österreichische Musikzeitschrift, 2009, Vol. 11-12, s. 46-49. ISSN 0029-9316. GA408/09/0484.

- FLAŠAR, Martin. Jan Novák and the Problem of National Identity in his Works. In 44th International Musicological Coloquium Brno. 2009.

- FLAŠAR, Martin. Návrat Jana Nováka do USA. In Musicologica Brunensia, 2009, 44, 1-2, s. 45-52. ISSN 1212-0391.

- FLAŠAR, Martin. Jan Novák, žák Bohuslava Martinů. Hudebni věda, 2006, 42, č. 1, s. 59-74.

- FLAŠAR, Martin a Jan ČIŽMÁŘ. Jan Novák - stav pramenů a bádání. Opus musicum, 2005, roč. 37, č. 1, s. 32-33. ISSN 0862-8505. 
Zkoumání těchto témat byla často heuristicky podpořena konzultacemi se členy rodiny Jana Nováka (jeho manželkou Eliškou Novákovou, dcerami Clarou a Dorou a bratrancem Richardem Novákem). Důležitá role připadá také části rodinného archivu uloženého na ÚHV FF MU. Stávající publikace nemohly vzniknout bez podpory ze strany dnes již zesnulých přátel a obdivovatelů Jana Nováka: Evžena Zámečníka a Zdeňka Cupáka.

Je zřejmé, že je třeba zvážit další otázky, například Novákův postoj k populární hudbě, organizaci hudebního života (včetně jeho role sbormistra), hodnocení jeho působení jako koncertního klavíristy nebo jeho poetických schopností v latinské poezii.

Paralelní výzkum provádí Eva Nachmilnerová, která se Novákovi věnuje jak odborně, tak v rámci popularizačních aktivit v Českém rozhlasu:

- NACHMilnerOVÁ, Eva. Passer Catulli a dodekafonie v díle Jana Nováka. Opus musicum, 37, 2005, č. 6, s. 55-60.

- NACHMILNEROVÁ, Eva.Jan Novák (1921-1984): Kapitoly z tvưrči biografie [Jan Novák (1921-1984): Chapters from His Creative Years]. Disertační práce. Karlova univerzita, Praha, 2013.

Současný výzkum vedený autorem tohoto příspěvku a Evou Nachmilnerovou doplňuje nedávná nálezová zpráva Pavla Žůrka:

- ŽŮREK, Pavel. Two Martinů scores from Jan Novák's personal effects. Martinů Revue, 2014, Vol. 14, No. 3, p. 4. ISSN 1803-8514.

Nová vlna výzkumu Jana Nováka navazuje zejména na starší články Aleny Němcové:

- NĚMCOVÁ, Alena. Novák, Jan. In Dizionario Enciclopedico Universale Della Musica e Dei Musicisti. Alberto Basso (ed.), Le Biografie, vol. 5, Turin 1988, $408 f$.

- NĚMCOVÁ, Alena. Prohibiti der tschechischen Musik: Jan Novák. Musiknachrichten aus Prag, 1991, 5-6, s. 2-5.

- NĚMCOVÁ, Alena. Vítězslava Kaprálová a Jan Novák: dva moravští žáci Bohuslava Martinů. Opus musicum 1991, č. 23, s. 190-193.

- NĚMCOVÁ, Alena. Vítězslava Kaprálová and Jan Novák: Two of Martinůs Moravian Pupils. Czech Music. The Journal of the Dvoŕák Society 1999-2000, 21, s. 174-180.

- NĚMCOVÁ, Alena. Novák, Jan. In The New Grove Dictionary, vol. 18, 2nd Edition 2001, s. 208-210.

Jak je patrné z uvedených bibliografických odkazů, výsledky výzkumu prováděného na pracích Jana Nováka dosud měly formu úzce vymezených témat, základních lexikálních záznamů nebo informačních článků. To, co odborná komunita postrádá, je syntetický pohled na kariéru Jana Nováka. Výzkum jeho kompozičních prací byl dříve omezen nedostupností zdrojů, které byly rozptýleny mezi městem Neu Ulm a brněnským rodinným archivem. 


\section{Cíle a výstupy projektu}

V současné době se naskýtá př́ležitost zahájit systematický výzkum archivních pramenů uložených v Českém muzeu hudby v Praze. Prvním logickým krokem na této cestě je výzkum vztahů mezi Janem Novákem a Bohuslavem Martinů na základě jejich vzájemné korespondence. Vztah žáka a učitele, později přátel, trval od jejich prvního setkání v New Yorku v roce 1947 až do smrti Martinů v roce 1959.

Z hlediska IBM je práce na představovaném projektu a jeho cíl úzce spjat s činností Institutu a významně rozšiřuje rozsah současného výzkumu pramenů k životu a dílu Bohuslava Martinů v rámci jeho současného biografického a kulturního kontextu: zpracování zcela nových pramenů, týkajících se se dobových souvislostí a vztahem mezi Martinů a jeho nejbližším studentem, světově proslulým skladatelem Janem Novákem, který se navíc výrazně a aktivně podílel na př́ípravě publikací některých kompozic Martinů (nap̌r. Polni mše, H 279). ${ }^{12}$ Existuje mnoho zjevných biografických, estetických a uměleckých paralel, které silně spojují oba skladatele a motivují další výzkum daného tématu.

Korespondence obou skladatelů byla nalezena v rámci předběžné sondy do pozůstalosti Jana Nováka v NM ČMH čítající 304 položek. Společný tým ÚHV FF MU a IBM zahájí systematickou muzikologickou práci na této pozůstalosti, která povede ke zpracování a zpř́ístupnění výsledků bádání odborné i široké veřejnosti. Systematický výzkum bude probíhat také ve více než 5000 dopisech a dalších dokumentech, jejichž kopie jsou uloženy v IBM v Praze. Výsledky výzkumu ve formě nově objevených zdrojů budou zaznamenány a zpracovány také v on-line databázi zdrojů www.database.martinu.cz a budou zpř́stupněny zájemcům o dané téma.

Kromě plánovaných průběžných publikací v odborných časopisech je hlavním plánovaným výstupem projektu bilingvní, česko-anglicky psaná monografie, jejiž nedílnou součástí bude kritická edice korespondence doplněná historiografickým úvodem do problematiky.

Tato studie vznikla v rámci grantového projektu GA ČR 19-06958S „Jan Novák a Bohuslav Martinů ve svètle vzájemné korespondence (1947-1959). Zpracováni a vydáni knižni monografie“.

\section{Bibliography}

BLATNÝ, Pavel. Tři zastavení s Janem Novákem. Hudebni rozhledy, 1990, roč. 18, s. 277.

FLAŠAR, Martin. Jan Novák, žák Bohuslava Martinů. Hudebni věda, 2006, roč. 43, č. 1, s. 59-74.

MARTINU゚, Charlotta. Můj život s Bohuslavem Martinů. Praha: Supraphon, 1971.

MIHULE, Jaroslav. Martinu: osud skladatele. Praha: Karolinum, 2002.

NOVÁK, Jan. Deníkové zápisky. Pozůstalost Jana Nováka. NM ČMH, Praha.

12 Na závěrečné téma Polní mše Novák zkomponoval Variace na téma Bohuslava Martinů. Verze pro dva klavíry je z roku 1949, instrumentovaná verze pro symfonický orchestr vznikla r. 1959. 
NOVÁK, Jan. Dopis Evženu Zámečníkovi, 17. 11. 1982. Tiskem in HRABAL, František. V kontextu tvorby. Praha: Arbor Vitae, 2006, s. 294.

NOVÁK, Jan. Poslední dopis Bohuslavu Martinů. Host do domu, VI, 1959, s. 462.

ZÁMEČNíK, Evžen. Osobní deníkový zápis ze setkání s Janem Novákem, Singen, 1982. Soukromý archiv E. Zámečníka.

ZOUHAR, Zdeněk (ed.). Bohuslav Martinů: Sbornik vzpominek a studii. Krajské nakladatelství v Brně, 1957. 